\title{
Evaluation of the Rice Establishment Methods for Higher Productivity and Profitability under Dry Seeded Condition
}

\author{
Om Prakash Bhaskar ${ }^{1}$, M. Kumar ${ }^{1}$, A. K. Thakur ${ }^{1 *}$, T. Chandrakar ${ }^{2}$ and D.P. Singh ${ }^{3}$ \\ ${ }^{1}$ Department of Agronomy, ${ }^{2}$ Department of Soil Science \& Agricultural Chemistry and \\ ${ }^{3}$ Department of Agricultural Statistics and Social Science (Lengauge), \\ Shaheed Gundadhoor College of Agriculture and Research Station, Jagdalpur, \\ Indira Gandhi Krishi Vishwavidyalaya Raipur, India \\ *Corresponding author
}

\begin{abstract}
A B S T R A C T
Keywords

Establishment method, Drum seeder, Direct seeded rice, Aerobic rice

Article Info

Accepted:

20 November 2019

Available Online:

10 December 2019

A field experiment was conducted during kharif 2018 at Instructional cum Research Farm of Shaheed Gundadhoor College of Agriculture and Research Station, Jagdalpur, Chhattisgarh under AICRIP in Alfisols to study grain yield of rice as influenced by different methods of establishment. Results revealed that significantly highest grain yield was registered under treatment dry direct seeded drum seeder $\left(\mathrm{T}_{1}\right)$ which was at par with treatments aerobic rice $\left(\mathrm{T}_{3}\right)$, semi dry rice $\left(\mathrm{T}_{4}\right)$ and transplanted rice $\left(\mathrm{T}_{5}\right)$. However, the lowest grain yield was recorded under treatment dry direct seeded rice $\left(\mathrm{T}_{2}\right)$. Further, significantly highest net return was recorded under treatment dry direct rice drum seeder method $\left(T_{1}\right)$ which was at with treatment aerobic rice unpuddled condition $\left(T_{3}\right)$. While lowest net return was noticed under treatment transplanted rice $\left(\mathrm{T}_{5}\right)$. Further, significantly highest $\mathrm{B}$ : $\mathrm{C}$ ratio was recorded under treatment dry direct rice drum seeder method $\left(\mathrm{T}_{1}\right)$ over rest of the treatments. Further, the lowest B: C ratio was noticed under treatment transplanted rice $\left(\mathrm{T}_{5}\right)$.
\end{abstract}

\section{Introduction}

Rice (Oryza sativa L.) is monocot plant belonging to genus Oryza under grass family Poaceae. Rice has the distribution of being the most extensively cultivated crop in the world and important staple food of more than $60 \%$ of the world population. Rice occupies an important among food crops under diversified situation. About $90 \%$ of all rice grown in the world is produced and consumed in the Asian region. In the world, $85 \%$ of the total rice area is in Asia. India is the second largest producer and consumer of rice in the world. The Chhattisgarh is known as "rice bowl of India" and about $82 \%$ population of the state is dependent on agriculture for their livelihood. The total rice grown area is 3.71 million hectares with the production of 7.29 million tonnes and productivity of 1.96 tonnes $\mathrm{ha}^{-1}$ (Krishi Darshika, 2019). Rice is grown by mainly two methods i.e. transplanting and 
direct seeding. Direct seeding can be done by either broadcasting or line sowing. In Chhattisgarh most of the rice growing area is under direct seeded rice. Direct seeded rice offers the advantage of faster and easier planting, ensure proper plant population, reduce labour and hence less drudgery 10-12 days earlier crop maturity, more efficient water use and higher tolerance to waterdeficit, and often high profit in areas with assured water supply (Datta, 1986). Drum seeder is an effective mean for timely sowing of rice. Also direct seeded rice may mature 7 to 10 days earlier than transplanted rice (Subbaiah et al., 2002). Dry direct seeding of rice allows early establishment of the succeeding crop and higher profit in areas with assured water supply by utilizing short duration modern varieties and cost efficient herbicides. So, there is need to search for suitable crop establishment methods to increase the productivity and profitability of rice (Farooq et al., 2011).

\section{Materials and Methods}

The location of the experimental site was Instructional cum Research Farm of Shaheed Gundadhoor College of Agriculture and Research Station, Jagdalpur, Chhattisgarh. It comes under Bastar plateau of Chhattisgarh which comprises of large plateau having elevation of $553 \mathrm{~m}$ above mean sea level and lies between $17^{\circ} 46^{\prime} \mathrm{N}$ and $20^{\circ} 34^{\prime} \mathrm{N}$ latitudes and $80^{\circ} 15^{\prime}$ and $82^{\circ} 15^{\prime} \mathrm{E}$ longitudes. The five different methods of establishment viz dry direct seeded rice unpuddled soil by drum seeder $\left(\mathrm{T}_{1}\right)$, dry direct seeded rice unpuddled condition by broadcasting $\left(\mathrm{T}_{2}\right)$, aerobic rice unpuddled condition by line sowing $\left(\mathrm{T}_{3}\right)$, semi-dry rice (unpuddled rice $12 \mathrm{hrs}$ water soaking) $\left(\mathrm{T}_{4}\right)$ and transplanted under puddled condition $\left(\mathrm{T}_{5}\right)$ were adopted. The experiment was laid out randomized block design with tree replications. The variety Samleswari was taken as a test crop. Matures in 105-112 days, grain type medium size grain, resistance to blast, moderately resistant/tolerant against blight, gall-midge, tolerate to drought and suitable for summer cultivation and yield potential is $35-45 \mathrm{q} \mathrm{ha}^{-1}$. The soil of the experimental site is characterized as silty loam (fairly leveled). The soil was locally known as Mal (Alfisols). It is well fertile soil belongs to mid land situation of topography in Jagdalpur. During kharif season 2018, a total of $1085 \mathrm{~mm}$ rainfall was recorded against the normal rainfall of $1195 \mathrm{~mm}$. With the onset of monsoon, $117.4 \mathrm{~mm}$ of rainfall was received during 23rd SMW. Total rainfall received during the June month was $178.1 \mathrm{~mm}$. In the months of July, August, September and October rainfall of 269.4, 421.4, 233.9 and 6.2 $\mathrm{mm}$ was received, respectively. The evapotranspiration, maximum and minimum temperature and wind velocity ranged between 1.2 to $7.9 \mathrm{~mm}, 26.8$ to $37.2{ }^{0} \mathrm{C}, 8.7$ to $24.3{ }^{0} \mathrm{C}$, and 1.7 to $7.9 \mathrm{~km}$ ph respectively.

\section{Results and Discussion}

Plant height, number of tillers hill ${ }^{-1}$, leaf area index as influenced by different establishment methods shown in Table 1.

The significantly taller plant was observed in treatment aerobic rice line sowing $\left(\mathrm{T}_{3}\right)$ at 30 DAE which was at par with treatments dry direct rice drum seeder method $\left(\mathrm{T}_{1}\right)$, dry direct seeded rice broadcasting method $\left(\mathrm{T}_{2}\right)$ and semi-dry rice method $\left(\mathrm{T}_{4}\right)$. While, shortest plant was recorded under transplanted rice method $\left(\mathrm{T}_{5}\right)$. At $60 \mathrm{DAE}$ significantly taller plant noticed under treatment dry direct rice using drum seeder method $\left(\mathrm{T}_{1}\right)$ which was on par with treatments dry direct seeded rice broadcasting method $\left(\mathrm{T}_{2}\right)$, aerobic rice line sowing method $\left(\mathrm{T}_{3}\right)$ and semi-dry rice method $\left(\mathrm{T}_{4}\right)$, and at 90 DAE plant height was found statistically non significant. In general, the plant height, dry matter production was found to increase with the age of the crop. While, 
tiller production starts slowly in the beginning, increases steadily and attains to its peak during panicle initiation stage and then started to decline as the age of the crop. The decrease in tiller number on aging resulted from death of the late forming tillers due to their incompetency for light and nutrients (Barik et al., 2006). Halder et al., (2010) stated that maximum plant height was recorded in SRI method, which was on a par with transplanting but significantly superior over broadcasting and drum seeding.

The significantly highest number of tiller hill ${ }^{-1}$ was registered with treatment aerobic rice unpuddled condition $\left(\mathrm{T}_{3}\right)$ at all the growth stages which was at par with treatments dry direct rice drum seeder method $\left(\mathrm{T}_{1}\right)$ and semi dry rice $\left(\mathrm{T}_{4}\right)$ at $30 \mathrm{DAE}$ and $60 \mathrm{DAE}$ and dry direct rice drum seeder method $\left(\mathrm{T}_{1}\right)$ at 90 DAE. Awan et al., (2007) reported maximum productive tillers $\mathrm{m}^{-2}$ (336) was found in direct seeded rice than manual transplanted crop (229 tillers $\mathrm{m}^{-2}$ ).

The leaf area index increased progressively from 30 DAE to 90 DAE. The leaf area index was more pronounced from 30 DAE to 90 DAE. Table 1 shows that significantly higher leaf area index was recorded in treatments dry direct rice by drum seeder $\left(\mathrm{T}_{1}\right)$ which was on par with aerobic rice line sowing unpuddled condition $\left(\mathrm{T}_{3}\right)$, semi dry rice $\left(\mathrm{T}_{4}\right)$ and transplanted rice $\left(\mathrm{T}_{5}\right)$ at 30,60 and 90 DAE and minimum leaf area index was recorded in treatment dry direct seeded rice by broadcasting. Transplanting shock can be avoided in direct rice than transplanting this result in growth delays and hastens physiological maturity and reduces vulnerability to late-season drought (Tuong 2008).

The dry matter accumulation was significantly influenced by different crop establishment methods. At all the growth stages, dry direct rice drum seeder method $\left(\mathrm{T}_{1}\right)$ registered significantly highest dry matter accumulation at 30, 60, and 90 DAE, which was at par with treatments. Kumar et al., (2018) revealed that among rice crop establishment methods direct seeded rice with drum seeder (DSR) was found most economic feasible method with high grain yield. Directseeded rice with drum seeder (DSR) had shorter crop duration, required less water and therefore had higher water-use efficiency than the transplanting method. Halder. (2009) observed that dry matter accumulation was significantly higher in direct seeded rice under puddle condition and SRI respectively compared to regular transplanting.

The significantly more time was required to $50 \%$ flowering was observed under treatment transplanted rice $\left(\mathrm{T}_{5}\right)$ which was at par with treatments dry direct seeded rice unpuddled condition $\left(\mathrm{T}_{2}\right)$, aerobic rice unpuddled condition $\left(\mathrm{T}_{3}\right)$ and semi dry rice $\left(\mathrm{T}_{4}\right)$. However, lowest days to $50 \%$ flowering was recorded under treatment dry direct rice drum seeder method $\left(\mathrm{T}_{1}\right)$ Table 2 . The number of panicle $\mathrm{m}^{-2}$ observed significantly highest under treatments dry direct seeded rice unpuddled condition $\left(\mathrm{T}_{2}\right)$, and lowest number of panicle $\mathrm{m}^{-2}$ was noticed under treatment semi dry rice $\left(\mathrm{T}_{4}\right)$ (Table 2$)$. Root volume, root dry weight given in Table 3 .

The significantly highest root volume was registered in treatment dry direct rice drum seeder method $\left(\mathrm{T}_{1}\right)$ during all the stages of observations which was at par with treatment dry direct seeded unpuddled condition $\left(\mathrm{T}_{2}\right)$ at $30 \mathrm{DAE}$ and 90 DAE. Lowest root volume was recorded under treatment transplanted rice $\left(\mathrm{T}_{5}\right)$ at all the durations (Table 3). The significantly highest root dry weight was observed under treatment semi dry rice $\left(\mathrm{T}_{4}\right)$ which was at par with treatments dry direct rice drum seeder method $\left(\mathrm{T}_{1}\right)$, dry direct seeded rice unpuddled condition $\left(\mathrm{T}_{2}\right)$ and 
aerobic rice unpuddled condition $\left(\mathrm{T}_{3}\right)$ at 30 DAE. Moreover, the lowest root dry weight was recorded under treatment transplanted rice $\left(\mathrm{T}_{5}\right) 30$ at DAE. While, $60 \mathrm{DAE}$ and $90 \mathrm{DAE}$ the highest root dry weight were observed under treatment. Further, the lowest root dry weight dry direct rice drum seeder method $\left(\mathrm{T}_{1}\right)$ recorded under treatment transplanted rice $\left(T_{5}\right)$ during $60 \mathrm{DAE}$ and $90 \mathrm{DAE}$.

Test weight, grain yield, straw yield and harvest index as influenced by different establishment methods (Table 4).

The highest test weight was recorded under treatment transplanted rice $\left(\mathrm{T}_{5}\right)$ which was at par with treatments dry direct seeded rice drum seeder $\left(\mathrm{T}_{1}\right)$ and aerobic rice $\left(\mathrm{T}_{3}\right)$. Further, the lowest test weight was observed under treatment semi dry rice $\left(\mathrm{T}_{4}\right)$. Drum seeding with uniform stand establishment, ideal rhizosphere environment might have contributed to higher nutrient uptake which resulted in the production of greater source and efficient translocation of photosynthates into the larger sink as indicated by higher yield attributes. Direct seeding of rice allows early establishment of the succeeding crop and higher profit in areas with assured water supply by utilizing short duration modern varieties and cost efficient herbicides (Balasubramanian and Hill, 2002). The significantly highest grain yield was registered under treatment dry direct rice drum seeder $\left(\mathrm{T}_{1}\right)$ which was at par with treatments aerobic rice $\left(\mathrm{T}_{3}\right)$, semi dry rice $\left(\mathrm{T}_{4}\right)$ and transplanted rice $\left(\mathrm{T}_{5}\right)$. However, the lowest grain yield $(\mathrm{kg}$ $\mathrm{ha}^{-1}$ ) was recorded under treatment dry direct seeded rice $\left(T_{2}\right)$. The significantly highest straw yield was noticed under treatment dry direct seeded drum seeder $\left(T_{1}\right)$ which was at par with rest of the treatments. Higher grain and straw yield in drum seeding was due to more mobilization of photosynthetic to grain. This is confirmation with the finding of Reddy (2010). Bautista and Gagelonia (1994) reported that row seeding using drum seeder was reported to have increased grain yield of 425 to $750 \mathrm{~kg} \mathrm{ha}^{-1}$ compared with broadcasting and transplanting and farmers income was increased by an average of 7.5 and $28 \%$ respectively, compared with broadcasting and transplanting. The significantly highest harvest index was recorded under treatment aerobic rice $\left(T_{3}\right)$ which was at par with treatments dry direct rice drum seeder method $\left(T_{1}\right)$, semi dry rice $\left(\mathrm{T}_{4}\right)$ and transplanted rice $\left(\mathrm{T}_{5}\right)$. The lowest harvest index was observed under treatment dry direct seeded rice unpuddled condition $\left(\mathrm{T}_{2}\right)$ (Table 4). Direct-seeding of rice has the potential to provide several benefits to farmers and the environment over conventional practices of puddling and transplanting. This may be due to the transplanting shock which may take about one week for establishment in transplanted rice.

Economics of rice as influenced by different establishment methods (Table 4).

Economics of rice influenced by different treatments is shown in Table 4. Significantly highest was gross return, net return and $\mathrm{B}$ : C ratio was recorded in treatments dry direct rice by drum seeder $\left(T_{1}\right)$ among all the treatments and lower net return and $\mathrm{B}: \mathrm{C}$ ratio was observed in treatments transplanted rice $\left(\mathrm{T}_{5}\right)$. Similar finding was reported by Ramasamy et al., (2006) 60 percent saving of labour during crop establishment stage (sowing, transplanting and weeding) as compared to transplanted rice. Rashid et al., (2009) obtained higher gross returns and $\mathrm{B}$ : $\mathrm{C}$ ratio in drum seeded rice than in transplanted rice. Farooq et al., (2011) noticed that dry direct seeding of rice allows early establishment of the succeeding crop and higher profit in areas with assured water supply by utilizing short duration modern varieties and cost efficient herbicides. 
Table.1 Plant height, number of tiller plant ${ }^{-1}$ and leaf area index at different durations of rice as influenced by different crop establishment methods

\begin{tabular}{|c|c|c|c|c|c|c|c|c|c|}
\hline \multirow[t]{2}{*}{ Treatment } & \multicolumn{3}{|c|}{ Plant height (cm) } & \multicolumn{3}{|c|}{ Number of tiller plant ${ }^{-1}$} & \multicolumn{3}{|c|}{ Leaf area index } \\
\hline & $30 \mathrm{DAE}$ & $60 \mathrm{DAE}$ & $90 \mathrm{DAE}$ & $30 \mathrm{DAE}$ & $60 \mathrm{DAE}$ & $90 \mathrm{DAE}$ & $30 \mathrm{DAE}$ & $60 \mathrm{DAE}$ & $90 \mathrm{DAE}$ \\
\hline $\begin{array}{l}\text { T1 : Dry direct seeded rice } \\
\text { unpuddled soil (Drum seeder) }\end{array}$ & 47.97 & 62.60 & 76.35 & 9.45 & 8.50 & 8.45 & 2.79 & 3.88 & 5.01 \\
\hline $\begin{array}{l}\text { T2 : Dry direct seeded rice } \\
\text { unpuddled condition } \\
\text { (Broadcasting) }\end{array}$ & 47.72 & 61.05 & 73.55 & 6.05 & 5.15 & 4.20 & 2.49 & 3.27 & 4.18 \\
\hline $\begin{array}{r}\text { T3: Aerobic rice unpuddled } \\
\text { condition (Line sowing) }\end{array}$ & 48.82 & 62.20 & 74.95 & 10.40 & 9.70 & 8.90 & 2.76 & 3.73 & 4.86 \\
\hline $\begin{array}{l}\text { T4 : Semi-dry rice (unpuddled rice } \\
12 \text { hrs water soaking) }\end{array}$ & 46.87 & 62.20 & 76.85 & 8.75 & 7.90 & 6.75 & 2.60 & 3.74 & 4.69 \\
\hline T5 : Transplanted (puddle condition) & 39.52 & 57.02 & 73.45 & 8.20 & 7.40 & 6.65 & 2.56 & 3.78 & 4.98 \\
\hline SEm \pm & 0.86 & 0.96 & 1.79 & 0.66 & 0.59 & 0.67 & 0.06 & 0.05 & 0.08 \\
\hline $\mathrm{CD}(\mathrm{P}=0.05)$ & 2.70 & 3.01 & NS & 2.06 & 1.84 & 2.11 & 0.20 & 0.17 & 0.27 \\
\hline
\end{tabular}


Table.2 Dry matter accumulation $\left(\mathrm{g}\right.$ hill $\left.{ }^{-1}\right)$, days to $50 \%$ flowering, number of panicle $\left(\mathrm{m}^{-2}\right)$ at different durations of rice as influenced by different crop establishment methods

\begin{tabular}{|c|c|c|c|c|c|}
\hline \multirow[t]{2}{*}{ Treatment } & \multicolumn{3}{|c|}{ Dry matter accumulation (g hill ${ }^{-1}$ ) } & \multirow{2}{*}{$\begin{array}{l}\text { Days to } 50 \% \\
\text { flowering }\end{array}$} & \multirow{2}{*}{$\begin{array}{l}\text { Number of panicle } \\
\qquad\left(\mathrm{m}^{-2}\right)\end{array}$} \\
\hline & $30 \mathrm{DAE}$ & $60 \mathrm{DAE}$ & $90 \mathrm{DAE}$ & & \\
\hline $\begin{array}{l}\text { T1 : Dry direct seeded rice unpuddled soil } \\
\text { (Drum seeder) }\end{array}$ & 9.20 & 40.78 & 47.26 & 77 & 277.5 \\
\hline $\begin{array}{l}\text { T2 : Dry direct seeded rice unpuddled } \\
\text { condition (Broadcasting) }\end{array}$ & 5.72 & 31.44 & 36.90 & 82 & 517.8 \\
\hline $\begin{array}{l}\text { T3: Aerobic rice unpuddled condition (Line } \\
\text { sowing) }\end{array}$ & 8.26 & 37.22 & 40.89 & 81 & 344.3 \\
\hline $\begin{array}{l}\text { T4 : Semi-dry rice (unpuddled rice } 12 \text { hrs } \\
\text { water soaking) }\end{array}$ & 7.68 & 36.11 & 38.88 & 80 & 268.0 \\
\hline T5 : Transplanted (puddle condition) & 7.47 & 39.41 & 43.13 & 84 & 310.0 \\
\hline SEm \pm & 0.61 & 1.32 & 1.47 & 1.29 & 43.57 \\
\hline $\mathrm{CD}(\mathrm{P}=\mathbf{0 . 0 5})$ & 1.92 & 4.11 & 4.59 & 4.04 & 135.76 \\
\hline
\end{tabular}


Table.3 Root volume and root dry weight as influenced by different crop establishment methods

\begin{tabular}{|c|c|c|c|c|c|c|}
\hline \multirow[t]{2}{*}{ Treatment } & \multicolumn{3}{|c|}{ Root volume (cc) } & \multicolumn{3}{|c|}{ Root dry weight (g) } \\
\hline & 30 DAE & 60 DAE & 90 DAE & 30 DAE & 60 DAE & 90 DAE \\
\hline $\begin{array}{l}\text { T1 : Dry direct seeded rice unpuddled soil } \\
\text { (Drum seeder) }\end{array}$ & 10.58 & 13.00 & 11.08 & 7.91 & 12.44 & 13.09 \\
\hline $\begin{array}{l}\text { T2 : Dry direct seeded rice unpuddled condition } \\
\text { (Broadcasting) }\end{array}$ & 8.99 & 11.01 & 9.25 & 7.61 & 9.35 & 10.55 \\
\hline $\begin{array}{l}\text { T3: Aerobic rice unpuddled condition (Line } \\
\text { sowing) }\end{array}$ & 7.66 & 10.50 & 8.83 & 7.45 & 8.48 & 9.24 \\
\hline $\begin{array}{l}\text { T4 : Semi-dry rice (unpuddled rice } 12 \text { hrs water } \\
\text { soaking) }\end{array}$ & 7.49 & 10.25 & 8.64 & 9.85 & 9.29 & 9.89 \\
\hline T5 : Transplanted (puddle condition) & 3.38 & 10.08 & 8.60 & 1.39 & 7.92 & 9.15 \\
\hline SEm \pm & 0.61 & 0.47 & 0.44 & 1.56 & 0.67 & 0.45 \\
\hline $\mathrm{CD}(\mathrm{P}=\mathbf{0 . 0 5})$ & 1.91 & 1.48 & 1.38 & 4.88 & 2.10 & 1.42 \\
\hline
\end{tabular}


Table.4 Test weight, Grain yield, Straw yield, harvest index, gross return, net return and B: C ratio as influenced by different establishment methods

\begin{tabular}{|c|c|c|c|c|c|c|c|}
\hline Treatment & $\begin{array}{c}\text { Test } \\
\text { weight } \\
\text { (g) }\end{array}$ & $\begin{array}{c}\text { Grain } \\
\text { yield } \\
\left(\mathrm{kg} \mathrm{ha}^{-1}\right)\end{array}$ & $\begin{array}{c}\text { Straw } \\
\text { yield } \\
\left(\mathrm{kg} \mathrm{ha}^{-1}\right)\end{array}$ & $\begin{array}{c}\text { Harvest } \\
\text { Index } \\
(\%)\end{array}$ & $\begin{array}{l}\text { Gross return } \\
\left(000 ₹ \text { ha }^{-1}\right)\end{array}$ & $\begin{array}{l}\text { Net return } \\
\left(000 ₹ \text { ha }^{-1}\right)\end{array}$ & B:C ratio \\
\hline $\begin{array}{l}\text { T1 : Dry direct seeded rice unpuddled } \\
\text { soil (Drum seeder) }\end{array}$ & 26.75 & 4651.5 & 5953.9 & 43.85 & 119263 & 89674 & 3.03 \\
\hline $\begin{array}{l}\text { T2 : Dry direct seeded rice unpuddled } \\
\text { condition } s(\text { Broadcasting) }\end{array}$ & 25.75 & 3721.2 & 5395.7 & 40.81 & 95727 & 65534 & 2.17 \\
\hline $\begin{array}{l}\text { T3: Aerobic rice unpuddled condition } \\
\text { (Line sowing) }\end{array}$ & 26.25 & 4437.3 & 5591.0 & 44.24 & 113727 & 82773 & 2.67 \\
\hline $\begin{array}{c}\text { T4 : Semi-dry rice (unpuddled rice } 12 \\
\text { hrs water soaking) }\end{array}$ & 25.50 & 4079.7 & 5344.5 & 43.29 & 104664 & 73710 & 2.38 \\
\hline T5 : Transplanted (puddle condition) & 27.25 & 4344.4 & 5647.7 & 43.47 & 111433 & 63194 & 1.30 \\
\hline SEm \pm & 0.323 & 188.4 & 197.8 & 0.65 & 96317 & 3.00 & 0.07 \\
\hline $\mathrm{CD}(\mathrm{P}=\mathbf{0 . 0 5})$ & 1.006 & 587.2 & 617.1 & 2.02 & NS & 10556 & 0.23 \\
\hline
\end{tabular}


In addition to labour savings, the demand for labour is spread out over a longer period in DSR than in transplanted rice (Kumar and Ladha, 2011). The test at Kerala Agricultural University showed that 77-81 per cent saving of labour and 48 per cent saving of cost as compared to manual transplanting (including nursery rising). The manual transplanting required 360 man (Anonymous 2000). Direct seeding helps reduce water consumption by about $30 \%$ ( 0.9 million liters acre $\left.^{-1}\right)$ as it eliminates raising of seedlings in a nursery, puddling, transplanting under puddled soil and maintaining 4-5 inches of water at the base of the transplanted seedlings. The farmer saves about ₹ 1400 acre $^{-1}$ in cultivation cost. Direct seeding (both wet and dry), on the other hand, avoids nursery raising, seedling uprooting, puddling and transplanting, and thus reduces the labour requirement (Pepsico International, 2011).

\section{References}

Anonymous. 2000. Research highlights. All India Co-ordinated project of Farm Implements and Machinery, CIAE, Bhopal.

Anonymous. 2019. Krishi Darshika, Indira Gandhi Krishi Vishwavidyalaya, Raipur (C.G.).

Awan, T. H., Ali, I., Safdar, M. E., Ashraf, M. M. and Yaqub, M. 2007. Economic effect of different plant establishment techniques on rice production. J. Agric, Res, 45(1):73-80.

Barik, A. K., Das, A., Giri, A. K. and Chattopadhyay, G. N. 2006. Effect of integrated plant nutrient management on growth, yield and production economics of wet season rice (Oryza sativa). Indian Journal of Agric. Sci. 76(11):657-60.

Bautista, E. U. and Gagelonia, E. C. 1994. Rice drum seeder. Technology LosBanos. 16(1): 24.
Datta, D. S. K. 1986. The biological yield and harvest index of cereals as agronomic and plant breeding criteria. Exp. Agric.22: 417-426.

Farooq, M., Kobayashi, N., Wahid, A. and Shadhzad M. A., Basra. 2011. Strategies for producing more rice with less water. Advance in Agronomy. 101:351-388.

Balasubramanian, V. and Hill, J. E. 2002. Direct seeding of rice in Asia: emerging issues and strategic research needs for the 21st century. Proceedings of the International Workshop on Direct Seeding in Asian Rice Systems: Strategic Research Issues and Opportunities, 25-28 January 2000, Bangkok, Thailand. Los Banos (Philippines): International Rice Research Institute. pp. 24-25.

Halder, J. 2009. Productivity and sustainability of different crop establishment methods for cultivation of rabi rice in western Orissa. Annals of Agri. Res., 30 (3\&4): 82-86.

Halder, J., Sahoo, K. C., Karmaker, S. K. and Nayak, R. N. 2010. Productivity and sustainability of different crop establishment methods for cultivation of rabi rice in Western Orissa. Annals of Agricultural Research New Series. 31 (1\&2):42-46.

Kumar, V. and Ladha, J. K. 2011. Direct seeding of rice: Recent developments and future research needs. Advances in Agron. 111: 297-413.

Kumar, V., Singh, S., Sagar, V. and Maurya, M. L. 2018. Evaluation of different crop establishment method of rice on growth, yield and economics of rice cultivation in agro-climatic condition of eastern Uttar Pradesh. Journal of Pharmacognosy and Phytochemistry. 7(3): 2295-2298.

Pepsico International. 2011. Direct seeding of paddy- the work of pepsico reported in indiawaterportal. 
www.indiawaterportal.org/post/6 754 .

Rashid, M. H., Alam, M. M., Khan, M. A. H. and Ladha, J. K. 2009. Productivity and resource use of direct-(drum)-seeded and transplanted rice in puddled soils in rice-wheat ecosystems. Field Crops Research, 113 (3): 274-281.

Reddy, G. S. 2010. Integrated weed management in drum seeding and direct planting system. M.Sc. (Ag.) Thesis. Tamil Nadu Agricultural University, Coimbatore, Tamil Nadu, India.

Ramasamy, S., Susheela, C. and Satyamoorty K. 2006. Direct planting system-Energy saving high output rice establishment technique for lowland. P 494. In
Abstract, Second International Rice Congress, New Delhi, India, 9-13 Oct. 2006.

Subbaiah, S. V., Balasubramanian, V. and Krishaiah, K. 2002. Evaluation of drum seeder in puddle field conditions. Agricultural Mechanization in Asia, Africa and Latin America. 33(4): 23-41.

Tuong, L. 2008. Studies on direct-seeding adaptability of Cambodian rice cultivars and development of cultivars with good eating quality. PhD thesis, Science of Plant and Animal Production, United Graduate School of Agricultural Science, Tokyo University of Agriculture and Technology, Japan.

\section{How to cite this article:}

Om Prakash Bhaskar, M. Kumar, A.K. Thakur, T. Chandrakar and Singh, D.P. 2019. Evaluation of the Rice Establishment Methods for Higher Productivity and Profitability under Dry Seeded Condition. Int.J.Curr.Microbiol.App.Sci. 8(12): 2654-2663.

doi: https://doi.org/10.20546/ijcmas.2019.812.310 